\title{
Organic Functions in a multiple economic entity - localization options. Case study
}

Dariusz Sobotkiewicz, Ph.D. Witelon University of Applied Sciences in Legnica

\section{Introduction}

Changes taking place in world economy with respect to society, economy and politics affect significantly daily work of multiple economic entities - concerns, holdings and multi-plant firms. Despite the fact that these large organization are more stable and resistant to environmental turbulences than small and medium businesses, management problems are more likely to occur. It is due to their complex structure, diversification of actions, excessive bureaucracy, and localization of economic entities in other countries than the corporate headquarters. Comparing multi-plant organizations to single-plant organizations it is easy to notice that the multi-plant ones have problems with placing organic functions in organizational structure. They consist of many business entities and each is capable of fulfilling the functions. Hence proper distribution of functions and their basic components within multi-plant entity is important as well as comprehensive, best if current, control of deployed localization solution. Changeable operating conditions for the organization are caused by many internal and external 
factors result in shifting the importance of each function, its content and range. What is more they are dislocated vertically and horizontally. One may come to the conclusion that nowadays the multi-plant organizations are constantly undergoing transformation with respect to fulfilling the functions.

This elaboration aims at identification of places where organic functions are fulfilled within the multi-plant organization and specifying the concentration and centralization level of functions. Theoretical assumptions have been empirically verified on the example of a German automotive concern. The answers for the following research questions were searched: What organic functions are fulfilled in the concern subsidiaries and what is the level of their concentration and centralization? The elaboration is based on thorough studies of domestic and foreign literature and the results of empirical research.

\section{Organic functions - essence and structure}

In every well-organized business entity functions that are necessary to achieving its goals should only be fulfilled. For this reason functions are called organic ${ }^{1}$. It should be noted that in each team or organizational unit organic functions are being fulfilled, thus basic ${ }^{2}$, auxiliary and regulatory (Przybyla 2002, p. 53). There are certain correlations between mentioned functions. Regulatory functions also known in literature as management functions cannot be present without basic and auxiliary functions. On the other hand basic and auxiliary functions could not be present without fulfilling regulatory functions. Their coexistence result from the fact that the components of management, namely planning, organization, motivation and controlling concern tangible as well as intangible resources of the organization. These resources are necessary to fulfill basic and auxiliary tasks. If production is a basic function and accounts an auxiliary one, then functions fulfillment of these two requires engaging people, machinery, financial resources and proper knowledge exploration, especially expertise, i.e. technology. Therefore someone is leading the people and is managing the organization. Then the one fulfills regulatory function. Correlations between mentioned functions illustrates picture 1:

1 See: (Ruhli 1990, nr 5; Scheffler, 1991, nr 2).

2 In production plant basic function is production, for trading company - sale, for service company

- providing the service. In these entities auxiliary functions will be personnel and accounts department. 


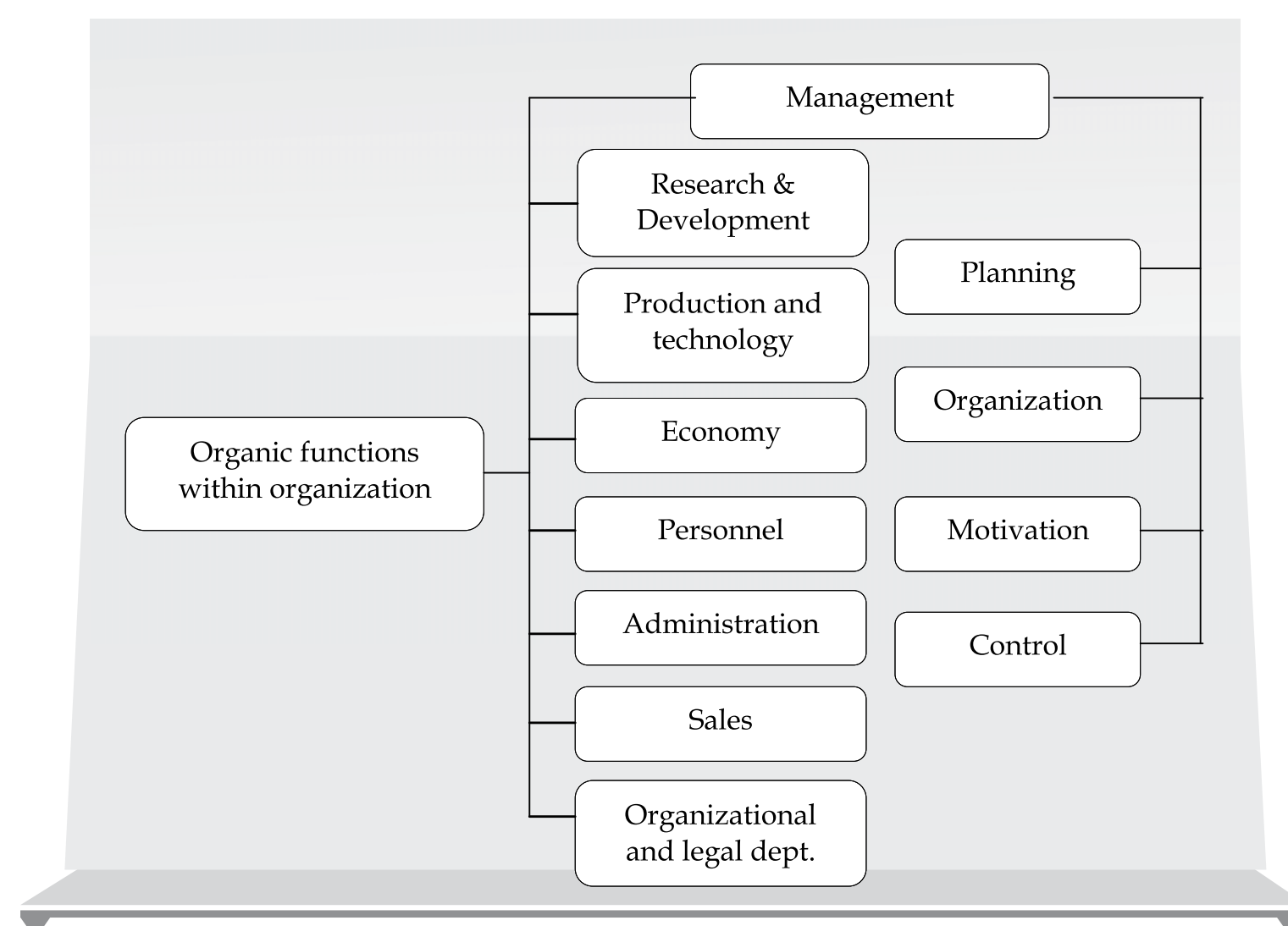

Picture 1. Organic functions unity within an organization

Source: Przybyla 2002, p. 53

It is worth adding that enterprises, especially those operating in modern branches, new functions appear such as product management and production management. Informatics and information technology grow in strength. The migration between functional areas within the enterprise is possible (Nowicki 2008, p.44). On one hand it is a response to dynamically changing operational environment of the companies, shortening products' life cycle ${ }^{3}$, constant growing competition, on the other hand the quest for increase of the effectiveness of business, cost reduction and increase in the efficiency of the organization.

3 See: (Gierszewska, Romanowska 2009, p.149).

49

DARIUSZ SOBOTKIEWICZ 


\section{Management concepts and organic functions fulfillment}

The managers are constantly striving for efficiency and effectiveness improvement in a way organization functions. One of the ways is to exert various management concepts. Implementation of these concepts leads to the changes in functions being fulfilled. Their contents and field is changed. Significance changes within time. Using outsourcing ${ }^{4}$ leads to limiting the scope of fulfilled tasks in function capacity. This can result in downsizing or relocation of employees to other organizational units.

The opposite is insourcing where external service providers delegate their tasks to their parent company. Then one can observe increasing the scope of function content, which leads to extension of the basic organizational units and creation new specialist positions. The increase of the significance of intangible resources such as knowledge and information fosters dynamic development of knowledge management concept and learning organization. Systemic thinking in category of processes rather than separate spheres and areas are also characteristic of these concepts. The organization creates conditions for the personnel and supports them in constant learning and improvement process. It is dynamic and open to new solutions. Task or project focused teams are created and their members possess expertise and experience for specific organic functions. Organizational structure leaning and flattening takes place. The dominant category of employees in such organizations are knowledge workers (De Wall A.). Lean management concept introduces significant changes, especially for production and supplies functions. Enterprise managed according to lean management concept in area of production has simple and clear technological processes, short cycle series, short set-up times and high production process integration. In supplies area the range and time of deliveries is precisely stated by manufacturer and the materials go directly to production (just-in-time rule), long term co-operation with limited number of suppliers takes place (Lichtarski 2001, p.266). Lean Management fosters management centralization and staff training. Process management concept breaks the traditional thinking which consequently leads to the transformation of the functions carried out. Some lose their importance.

4 M. Trocki (Trocki 2001, p.61) believes that taking the decision about using outsourcing should be preceded by asking the following questions: Will the fulfillment of functions separated be more efficient and more effective outside the company? Will placing the responsibility for the function separated on the external entity allow achieving tangible and intangible benefits? Positive response to these questions can be the trigger for starting the outsourcing. 
Others begin to play an increasing role. Merge and split functions processes become common. Process thinking takes first place, not thinking in the context of the functional areas. Through observing business practice one can notice that there is the change taking place with respect to managing human resources within the company ${ }^{5}$. Different concepts of managing human resources are created and developed. Therefore, personnel function becomes more significant. Competence centers are created to organize thematic training for the staff, plan the career, and equip the newly recruited employees with expertise. Quality of staff training is in the forefront as well as fast and conflict-free implementation into the job, which results in speeding up adaptation process of the new staff. These transformations have their roots in (Bouchikhi H., Kimberly J. 2003, p.126; Pocztowski 2010, p.264):

- seeing a human being as autonomous and thinking,

- wide-spread knowledge and information,

- treating the work-related aim as a part of life plan,

- independence of an individual as the basis for identifying with the company/ occupational group,

- seeing conflict as a component of life,

- new approach for division of labor is characterized by common decision and execution of responsibilities by both the staff and the management,

- widespread and divisible authority.

Taking these changes into account in structural solutions on the level of a unit as well as global organization which fulfill personnel function seems to be particularly important. The changes presented above that take place with respect to organic functions, triggered by implementation of management concept, affect the changes in their placement in a structure of a multiple economic entity. Obviously, this is not the only factor that decides. Shortening products' life cycle, stronger competition and other factors mentioned contribute to determining the changes.

\section{Distribution of organic functions in the structure of a multiple economic entity}

This elaboration takes J.Kozinski's assumption (Kozinski 1996, pp.49-50) that by subject distribution of organic functions will be considered within the scope

5 See: (Pocztowski 2010, pp.256-273).

51

DARIUSZ SOBOTKIEWICZ 
of their centralization and concentration ${ }^{6}$. The synthetic description of the distribution of functions is presented in picture 2 .

\begin{tabular}{|c|c|c|c|c|}
\hline & & \multicolumn{3}{|c|}{ CONCENTRATION } \\
\hline & & Low & Moderate & High \\
\hline \multirow{3}{*}{$\begin{array}{l}\mathrm{C} \\
\mathrm{e} \\
\mathrm{n} \\
\mathrm{t} \\
\mathrm{r} \\
\mathrm{a} \\
\mathrm{l} \\
\mathrm{i} \\
\mathrm{z} \\
\mathrm{a} \\
\mathrm{t} \\
\mathrm{i} \\
\mathrm{o} \\
\mathrm{n}\end{array}$} & $\begin{array}{c}\mathrm{H} \\
\mathrm{i} \\
\mathrm{g} \\
\mathrm{h}\end{array}$ & No occurance & No occurance & $\begin{array}{l}\text { Given function group is } \\
\text { entirely and exclusively } \\
\text { executed by the parent } \\
\text { company for all the } \\
\text { subsidiaries. }\end{array}$ \\
\hline & $\begin{array}{l}\mathrm{M} \\
\mathrm{o} \\
\mathrm{d} \\
\mathrm{e} \\
\mathrm{r} \\
\mathrm{a} \\
\mathrm{t} \\
\mathrm{e}\end{array}$ & $\begin{array}{l}\text { Given organic } \\
\text { function group is } \\
\text { partly executed by the } \\
\text { parent company and } \\
\text { partly (proportionally } \\
\text { bigger) by each of the } \\
\text { subsidiaries in the scope } \\
\text { of their competence } \\
\text { (each subsidiary fulfills } \\
\text { the function itself). }\end{array}$ & $\begin{array}{l}\text { Given organic function } \\
\text { group is partly executed } \\
\text { by the parent company } \\
\text { and partly (proportionally } \\
\text { bigger) by some of } \\
\text { the subsidiaries that } \\
\text { provide services to other } \\
\text { subsidiaries due to similar } \\
\text { action subject, area or } \\
\text { market. }\end{array}$ & $\begin{array}{l}\text { Given organic function } \\
\text { group is executed: } \\
\text {-partly by the parent } \\
\text { company } \\
\text {-or one of the subsidiaries } \\
\text {-or specially created } \\
\text { service company. }\end{array}$ \\
\hline & $\begin{array}{c}\mathrm{L} \\
\mathrm{O} \\
\mathrm{W}\end{array}$ & $\begin{array}{l}\text { Given organic function } \\
\text { group is entirely } \\
\text { executed only by } \\
\text { subsidiaries, each for } \\
\text { itself. }\end{array}$ & $\begin{array}{l}\text { Given organic function } \\
\text { group is partly executed } \\
\text { by some subsidiaries that: } \\
\text { provide assistance to other } \\
\text { group units, related due to } \\
\text { similar action subject, area } \\
\text { or market. }\end{array}$ & $\begin{array}{l}\text { Given function group is } \\
\text { entirely and exclusively } \\
\text { executed by: } \\
\text { - one of the subsidiaries } \\
\text {-or specially created } \\
\text { service company. }\end{array}$ \\
\hline
\end{tabular}

Picture 2. Distribution of organic functions by subject

Source: Kozinski 1996, p .53

Organic functions localization options for business entity presented in the picture 2 were verified empirically on an example of German automotive branch concern. Results of the study are presented in research part of this elaboration.

6 See: (Hugenberg 1992, nr 6; Bühner 1993, nr 1). 


\section{Research aims and methodology}

The aims of the research were to recognize the location of organic functions in the structure of a German concern and specify the level of their centralization and concentration. With that in mind the following research questions were asked:

1. What organic functions are fulfilled in each subsidiaries of the concern?

2. What is the level of centralization and concentration of the functions?

To answer these questions the results of conducted studies in a German concern in 2012 and 2013 were used. The research project ${ }^{7}$ was described in table 1.

Table 1. Research project description

\begin{tabular}{l|l}
\hline \multicolumn{2}{c}{ Research description } \\
\hline Research methods & $\begin{array}{l}\text { - Survey } \\
\text { - Interview } \\
\text { - Analysis of secondary sources (organizational structure, } \\
\text { organizational rules) }\end{array}$ \\
\hline Research tools & $\begin{array}{l}\text { - The survey was about the distribution of organic functions. } \\
\text { - Interview questionnaire consisted of four questions. All the } \\
\text { respondents were asked the questions. The aim for the interview was } \\
\text { to get the insights and clearing out any doubts or unclear information } \\
\text { found during the analysis of collected data in questionnaires. }\end{array}$ \\
\hline Research time & - September 2012 - July 2013. \\
\hline Respondents & - 1st group - Directors in subsidiaries (5 people) \\
& $\begin{array}{l}\text { 2nd group - executive directors from the corporate headquarters } \\
\text { (10 people) }\end{array}$ \\
\hline
\end{tabular}

Source: own elaboration on the basis of conducted research

To validate the questionnaire, mainly in the scope of its terminology ${ }^{8}$, each question was consulted with the managers from the corporate headquarters. Gathered information allowed the final creation of the questionnaire's form and content.

7 Data presented in this elaboration is only a part of gathered information in the research process.

8 The questionnaire contained terms which were irreplaceable with more understandable words, i.e.: organic function, distribution of organic functions, changes in the scope of functions etc. 


\section{Characteristic of the study group}

The subject of the study was German group of companies in automotive branch manufacturing components and end-products for its holder - the Volkswagen concern. The structure of the study group was depicted in picture 3 .

The study group with all its subsidiaries has been pursuing the Mach18 strategy since 2011. There are four strategic areas for this strategy:

- customer, quality, process (customer, quality and process orientation),

- employee (investing in employees' development),

- finance (financial stability),

- growth (expansion of the plant).

From the assumption pursuing such strategy aims at achieving the position of market leader in automotive industry by Volkswagen by 2018 .

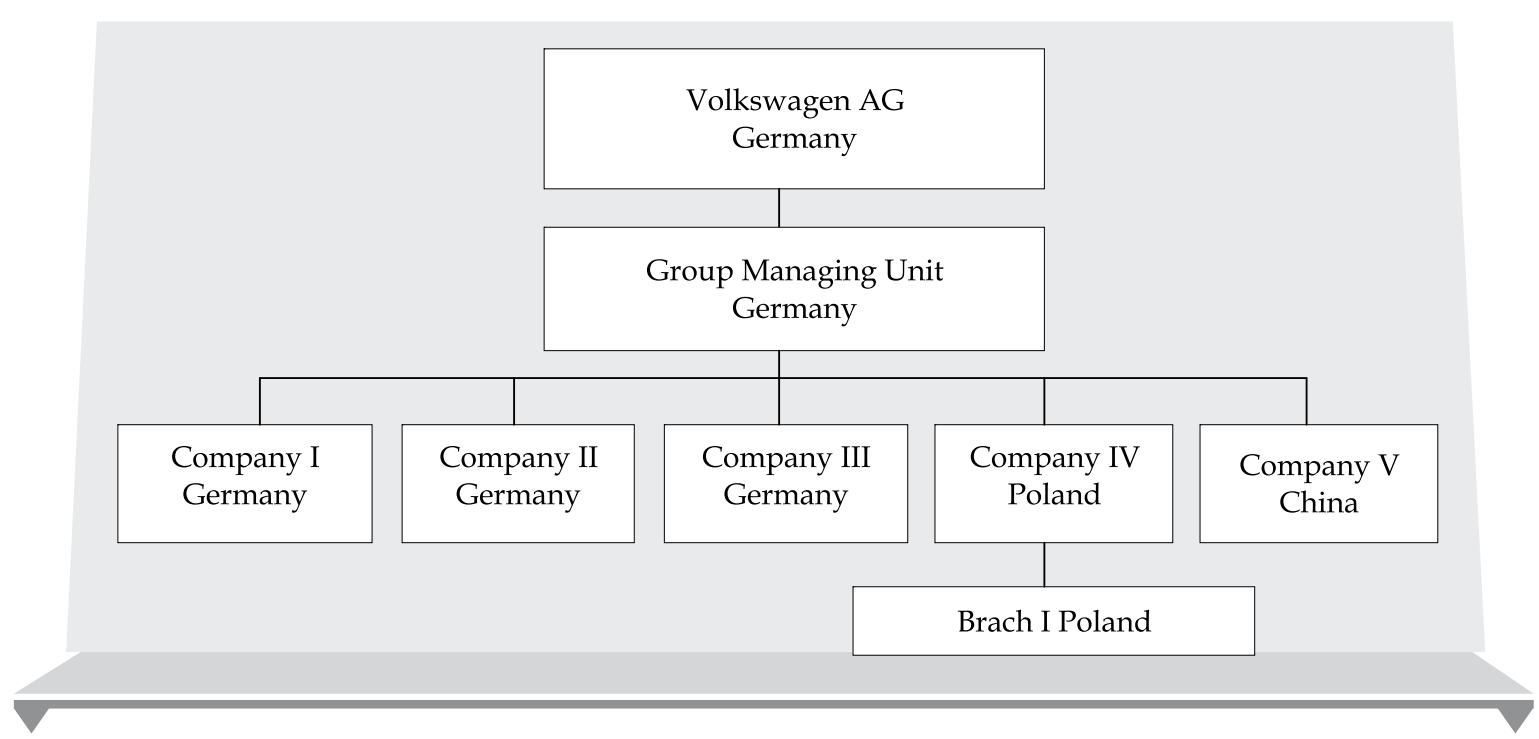

Picture 3. Organizational Structure of study group

Source: own elaboration based on conducted research

Core competence and the number of staff in each company shows Table 2. Polish institution manufactures necessary metal components, which are later sold to, for instance, other group entities, which use them to assemble the endproducts. 
Table 2. Characteristics of particular subsidiaries

\begin{tabular}{c|c|c}
\hline Company/Localization & Object of activity & Number of employees \\
\hline Group's HQ & Assembly of finished products & 600 \\
\hline Company I Germany & Assembly of finished products & 1400 \\
\hline Company II Germany & Assembly of finished products & 400 \\
\hline Company III Germany & Assembly of finished products & 300 \\
\hline $\begin{array}{c}\text { Company IV Poland } \\
\text { Branch I Poland }\end{array}$ & $\begin{array}{c}\text { Production of components } \\
\text { Production of components }\end{array}$ \\
\hline $\begin{array}{c}\text { Company V Chiny } \\
\text { Assembly of finished products } \\
\text { Production of components }\end{array}$ & 380 \\
\hline
\end{tabular}

Source: own elaboration based on conducted research

\section{Research results}

The first research issue was identifying organic functions location within the structure of researched concern. Research results in this area are presented in picture 4 . What is more to systemize the functions they were divided into two categories: technical aspect functions and economical aspect functions. From the analysis of the secondary resources, respectably organizational structures and group rules one may come to the conclusion that central functions are located within the superior unit, that on the level of the companies take the form of executive functions. Dual dependency of subsidiary functional managers has been identified. They are dependent from their superiors in subsidiaries and functional managers from the concern's headquarters.

Basic functions fulfilled in each entity is production. For that crucial is providing many auxiliary functions. In the researched group they are independently fulfilled by staff of each subsidiary. Outsourcing may not be affected. In the opinion of the managers, the corporate headquarters takes key decisions not only in terms of strategy but also has the right to intervene in operational issues. All the initiatives, ideas that comes from the bottom are being analyzed at the level of superior unit in terms of possible gains for the organization in global. They are well-seen and easily acceptable. Conditions for constant development of competence and rising qualifications are created. Meetings in the superior entity 
are held periodically and inspection of subsidiaries takes place. When it comes to communication, due to great distances video conferences are used. These allow to verbalize problematic issues and speed up decision-taking process. Novel tools for gathering, processing and sharing knowledge are incorporated. IT function gains importance in the group. Departments for informatics and information technology are being expanded. Quality function in subsidiaries is dependent upon the process control. The legitimacy of such organizational solution is firstly in specific of automotive industry, which is characterized by strong competition, and the key to success is the quality of any given component that consists in construction of a car, for example. Secondly, despite the fact that study group has precedence in providing parts to Volkswagen companies, it is still competing for new projects with other companies outside the group. Hence the corporate headquarters' functional director has the power to hold the manufacture of components and finished products without consultation with the companies' directors. Analyzing the companies with respect to location of new functions, the most developmental is the Polish Company. In recent two years legal and organizational departments have been separated from the structure as well as product management where, for instance, tasks concerning marketing, obtaining new contracts, competition inquiry and maintaining futures are fulfilled. What is more in 2013 a new production oriented branch has been created as a response to growing customers' demands. The branch in terms of auxiliary functions is supported by the Polish company. Comparing the subsidiaries within the group due to content of tasks involved in the specific functions, the most comprehensive organizational units can be seen in the Polish company. This testifies to the number of employees, namely 1725 people, of which almost 400 is partly the production staff. Worth noticing is also the fact of dynamic development of technical development function and technical planning function. This results in the situation when in Poland new prototypes of products are created and Polish managers have the power to take decisions independently.

In all of the German companies the same functions are present. They are under close inspection of the corporate headquarters. The most expanded are the ones for production department. The rest of the units are strongly supported by the superior unit. In comparison to the Polish company the range of tasks with respect to technical development is very limited. Within this function information about problems in implementation of new projects is gathered and sent to the headquarters. In each company there is one employee responsible for technical development. 


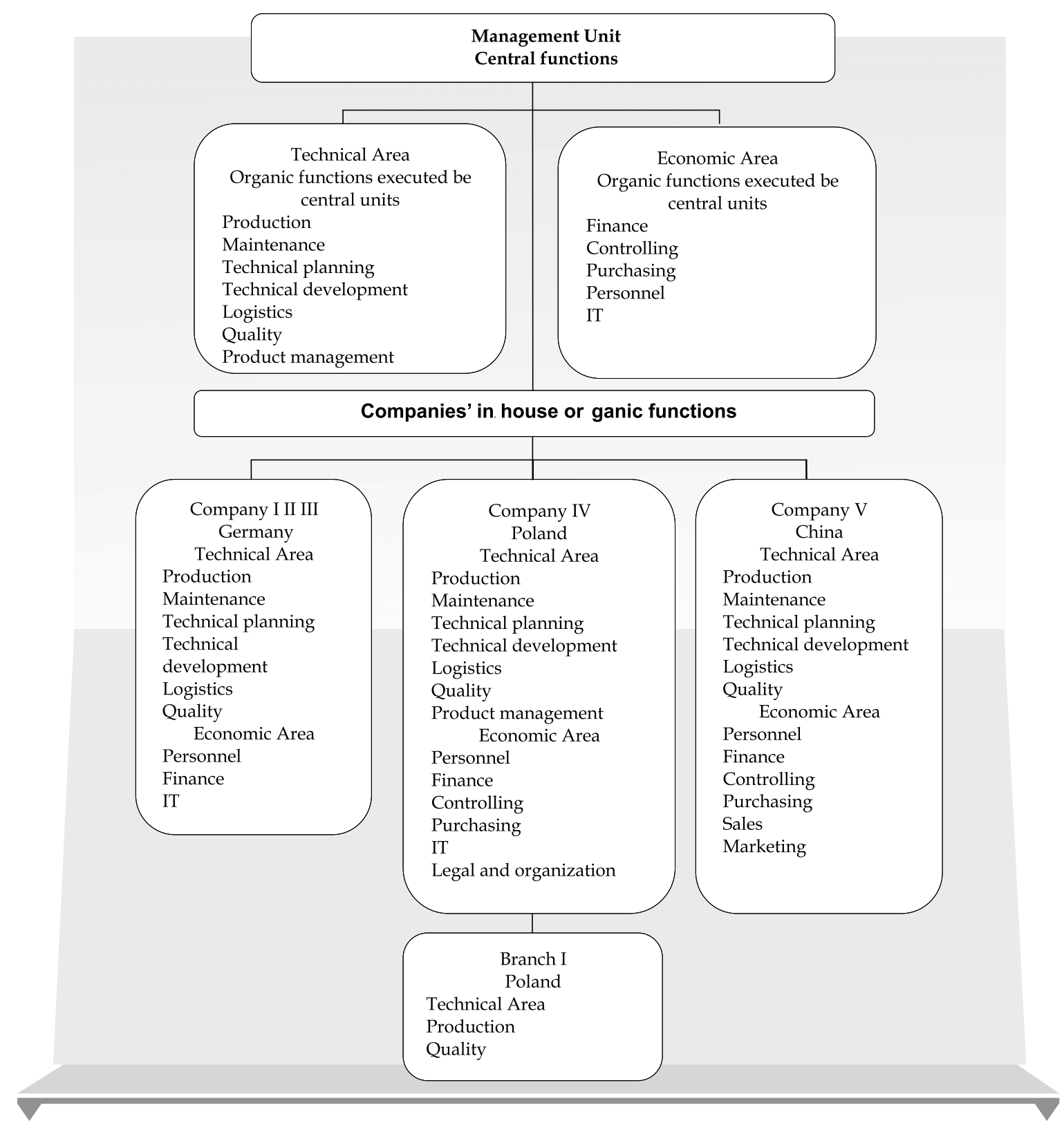

Picture 4. Organic functions location in German concern's structure

Source: own elaboration based on conducted research

In subsidiary in China one can observe the full scope of functions, like in typical company. According to the HQ managers it was due to: 
- great distance between Germany and China,

- proximity to major customers, Volkswagen subsidiaries located in China,

- geographical expansion, construction of a new point of sales in China.

For that reason, only in that subsidiary typical market functions are located: marketing and sales.

Another research problem was to determine the degree of centralization and concentration of organic functions. An attempt to verify the ways of arranging the functions argued by J.Kozinski was taken. Due to the fact that this elaboration is limited in space to present this issue of research the results gathered during the research in German concern were used.

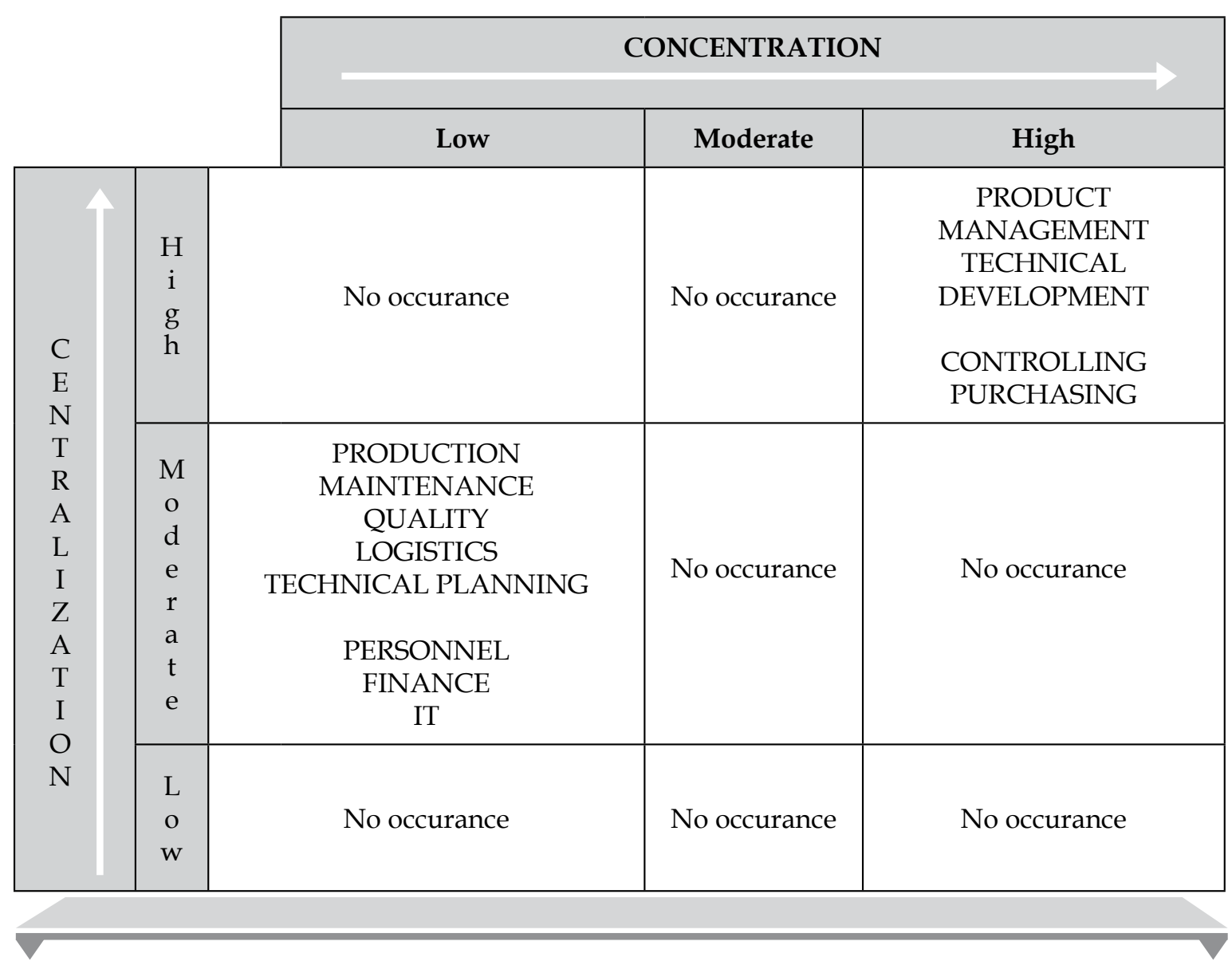

Picture 5. Centralization and concentration of organic functions

Source: own elaboration based on conducted research 
Conducted research allowed to identify two location options for organic functions in the structure of German study group, called: high centralization - high concentration and moderate centralization - low concentration. The analysis of the first location option leads to the conclusion as follows:

In technical area high concentration and centralization concerns product management and technical development function. The corporate headquarters supports the subsidiaries in these assignments correlated with the functions mentioned. As for product management, the superior unit's personnel obtains new production projects, which are then started in German subsidiaries. Also business contacts with the customers are the corporate headquarters' duty. Technical development, as well as product management, is the responsibility of HQ's personnel, where new production projects and prototypes are developed. Next they are implemented in the subsidiaries. The functions for economic area such as purchasing and controlling are centralized. According to the corporate headquarters' managers central purchases foster savings, as it is easier to negotiate with customers longer payment periods and lower prices if large scale purchases are made. It is the centralization of purchases that fosters this situation. Due to similar (nearly identical) nature of production in German subsidiaries, controlling function was placed at the level of corporate headquarters. The managers emphasized also the fact, that proximity of the headquarters to the subsidiaries influenced the decision as well as narrow range of products and developed IT systems amongst the group.

In case of second location option one can come to the following conclusions:

Fulfilling production functions entails carrying out many assignment of supportive nature, in subsidiaries by their personnel. Certain assignments cannot be carried out from corporate headquarters, operational management of in-house logistics to be mentioned and continuous machine and device maintenance, conducting personal matters of employees or recruitment process for production posts etc. Hence to keep the continuity of work it is crucial to locate certain functions and within them allocate the necessary powers of decisionmaking. In the study group these are maintenance, quality, logistics, technical planning, personnel, finance and IT (moderate centralization). Location of these functions in each of the German subsidiaries fosters low concentration.

\section{Conclusions}

The presented issue of organic functions arrangement in a multiple economic entity fits in the contemporary management topics of such 
big and complex entities. There is no universal model (variant, way) for deployment in the structure of economic organization. Ongoing monitoring of implemented localization variants from the perspective of benefits that contribute to the entire organization is important. Functions centralization as well as decentralization, their concentration or division has advantages and disadvantages and choosing proper variant is affected by many factors and conditions. In this elaboration based on the example of an automotive industry concern two function localization solutions, of high and moderate centralization, had been implemented. The subsidiaries stay under constant control of their parent company. It has its reasons especially in globalization era, uncertain operational environment as well as increasing competition.

\section{Summary}

Organic Functions in a multiple economic entity - localization options. Case study

Objective of this study is to identify localizations of fulfilling organic functions within organizational structure in a multiple economic entity and determination of the degree of their centralization and concentration. The nature of this elaboration is theoretical and empirical. The theoretical part presents depending that takes place in management, basic and auxiliary functions. Their inseparability was indicated, they are integrated. What is more, changes in the function areas, for instance caused by use of various management concepts, were shown. In the final part of the theoretical considerations matrix is shown in terms of subject distribution of organic functions. Empirical part focuses on verifying the theoretical assumptions, especially function location. The research had been conducted in all of the subsidiaries of a German automotive industry concern. The following research question was pursued: What organic functions are fulfilled in the subsidiaries and what degree of centralization and concentration is present? Elaboration ends with presentation of conclusions and references.

Key words: Concern, group of companies, superior unit, corporate headquarters, subsidiary, organic functions, centralization/concentration of functions. 


\section{Streszczenie}

Funkcje organicznew wieloczłonowym podmiociegospodarczym - warianty lokalizacyjne. Studium przypadku

Celem opracowania jest rozpoznanie miejsca realizacji funkcji organicznych $\mathrm{w}$ strukturze organizacji wielopodmiotowej oraz określenie ich stopnia centralizacji i koncentracji. Opracowanie ma charakter teoretyczne - empiryczny. W części teoretycznej przedstawiono zależności jakie zachodzą między funkcjami zarządzania, podstawowymi i pomocniczymi. Wskazano na ich nierozdzielność, zintegrowanie. Ponadto ukazano zmiany zachodzące $w$ obszarze funkcji wywołane stosowaniem m.in. wybranych koncepcji zarządzania. W części końcowej rozważań teoretycznych ukazano macierz w ujęciu podmiotowym rozmieszczenia funkcji organicznych. Weryfikacja założeń teoretycznych zwłaszcza wariantów lokalizacji funkcji stanowi przedmiot rozważać części empirycznej opracowania. Badania przeprowadzono we wszystkich zakładach niemieckiego koncernu z branży motoryzacyjnej. Poszukiwano odpowiedzi na następujące pytania badawcze: Jakie funkcje organiczne są realizowane $\mathrm{w}$ poszczególnych przedsiębiorstwach koncernu oraz jaki jest ich stopień centralizacji i koncentracji? Opracowanie kończy się prezentacją wniosków oraz spisem literatury.

Słowa

kluczowe: Koncern, grupa przedsiębiorstw, jednostka nadrzędna, jednostka zależna, funkcje organiczne, centralizacja/koncentracja funkcji.

\section{References}

1. Bouchikhi H., Kimberly J. (2003), Zmiana układu sił w przystosowanym środowisku pracy, w: J. Pickford (oprac.), Zarządzanie zasobami ludzkimi dla studentów MBA, Wydawnictwo Liber, Warszawa.

2. Bühner R. (1993), Die schlanke Management - Holding, Zeitschrift für Organisation, nr 1 .

3. Gieraszewska G., Z. Romanowska (2009), Analiza strategiczna przedsiębiorstwa, PWE, Warszawa.

4. Hugenberg H. (1992), Die Aufgaben der Zentrale, Zietschrift für Organisation, nr 6.

5. Lichtarski J. (red) (2001), Podstawy Nauki o przedsiębiorstwie, Wydawnictwo Akademii Ekonomicznej im. Oskara Langego we Wrocławiu, Wrocław. 
6. Koziński J. (1996), Lokalizacja funkcji organicznych w strukturze ugrupowania gospodarczego, Wydawnictwo Akademii Ekonomicznej im. Oskara Lanego we Wrocławiu, Wrocław.

7. Nowicki A (2008), Technologie informacyjne dla ekonomistów. Narzędzia. Zastosowania, Wydawnictwo Uniwersytetu Ekonomicznego we Wrocławiu, Wrocław.

8. Pocztowski A. (2010), Zarzadzanie zasobami ludzkimi wobec dotychczasowych doświadczeń i przyszlych wyzwań, w: S. Lachowicz, B. Nogalski (oprac.) Osiagnięcia i perespektywny nauk o zarządzaniu, Oficyna a Wolters Kluwer Business, Warszawa.

9. Przybyła M., (2001) (red), Organizacja i zarzadzanie. Podstawy wiedzy menedżerskiej, Wydawnictwo Akademii Ekonomicznej im. Oskara Langego we Wrocławiu, Wrocław.

10. Ruhli R. (1990), Zeitgemässe Konzernführung und Gestaltung, Zeitschrift für Organisation, nr 5.

11. Scheffler W. (1991), Grundzüge der Besteuerung von inländischen Konzernen, Die Betriebswirtschaft, nr 2.

12. Trocki M. (2001), Outsourcing. Metoda restrukturyzacji dziatalności gospodarczej, PWE, Warszawa.

13. Wall De A. (2007), Utrzymać się w lidze mistrzów, Manager magazine, nr 3. 